\title{
CSOMAGOLÁS TESZTELŐ BERENDEZÉS TERVEZÉSE
}

\author{
Majoros Péter \\ hallgató, Miskolci Egyetem \\ Gép- és Terméktervezési Intézet \\ 3515 Miskolc,Miskolc-Egyetemváros, e-mail: majorospeter@gmail.com \\ Takács Ágnes \\ egyetemi docens, Miskolci Egyetem \\ Gép- és Terméktervezési Intézet \\ 3515 Miskolc, Miskolc-Egyetemváros, e-mail: takacs.agnes@uni-miskolc.hu
}

\begin{abstract}
Absztrakt:
Napjainkban világszerte egyre jellemzőbb az online vásárlás, ennek is köszönhetöen a csomagszállitás egyre nagyobb méreteket ölt. Elengedhetetlen az áruk védelme és a vevök elégedettsége érdekében a megfelelö csomagolás biztositása. A megfelelö csomagolás biztositásához szükséges bizonyos szintü csomagolástechnikai ismeret, melyet a Miskolci Egyetem Gép-és Terméktervezési Intézete is oktat Csomagolástechnika c. tárgy keretein belül. A tervezési feladat célja egy tesztelö berendezés tervezése, amely a fent emlitett tantárgy gyakorlati óráihoz nyújt majd segitséget.
\end{abstract}

Kulcsszavak: tervezés, csomagolás, tesztelö berendezés

\section{Abstract:}

Nowadays, online shopping is becoming more and more popular all over the world. It is important to ensure proper packaging for the protection of the goods and customer satisfaction. Providing the right packaging it is necessary to have a certain level of knowledge in packaging technology that is taught by the Institute of Machine and Product Design in the frame of Packaging Technology course at the University of Miskolc. The purpose of the design task is to design a testing device that will assist with the practical lessons of the above-mentioned subject.

Keywords: design, package, testing device

\section{Bevezetés}

A csomagokat érő terhelések lehető legmagasabb szintủ reprodukálása végett, a cél egy ejtővizsgáló berendezés tervezése (1. ábra), amely alkalmas kis- és közepes méretü csomagok (maximum $600 \mathrm{~mm} x$ $360 \mathrm{~mm}$ x $620 \mathrm{~mm}, 25 \mathrm{~kg}$ ) vizsgálatára egyaránt [5]. A vizsgálat menete: különbözö, jól meghatározott pozíciókban (lapjára, élére, sarkára) elhelyezve a csomagot, a vizsgálati magasság beállítását követően egy merev talpazatra ejtik a csomagot.

A tervezés során figyelembe kell venni, hogy a cél egy prototípus berendezés megépítése, nem pedig sorozatgyártás továbbá, hogy a Gép- és Terméktervezési Intézetben számos ISEL elem rendelkezésre áll, így a konstrukciós megoldás során törekedtem az ISEL cég katalógusából (www.isel.hu) kiválasztani a szükséges elemeket. 
Távlati cél a berendezés továbbfejlesztése, pontos 3D-s modell készítése, majd véges elemes szoftverrel történő analizálás után a modell megépítése. Éppen ezért a tervezés során az egyszerüség és az alacsony költség a legföbb irányelv.

Ötletgyüjtés céljából a www.espacenet.com és a www.google.hu/PATENTS oldalak segítségével szabadalomkutatás elvégzésére került sor. Emellett piackutatás is történt. Melyek eredményeképpen többek között két nagyon hasznos funkcionális részegység került megfogalmazásra: az egyik a billenő tálca, amelyről a vizsgált csomagot le lehet ejteni, a másik pedig a pozicionáló rúd, amivel pozícióban lehet tartani a csúcsára állított csomagot.

A koncepcionális tervezés során több lehetséges megoldásváltozat közül Copeland módszer segítségével került kiválasztásra az a változat, amely a további tervezési munkálatok alapját képezi. [6, 7]

A konstrukciós tervezés kezdeti szakaszában a tálca pozíciójának beállítására három különféle megoldási elv került elemzésre:

- fogaskerék-fogasléc kapcsolat,

- targonca jellegü felvonó,

- emelőorsós megoldás.

Konstrukciós okokból a továbbiakban ez utóbbi, emelőorsós változat került kidolgozásra.

\section{Az emelőorsós változat kidolgozása}

A konstrukciós tervezés során a szabadkézi ábrák mellett a Solid Edge 9. verziójában (ST9) készült el a berendezés 3D-s modellje, amely a későbbi továbbfejlesztés alapjául szolgál majd. [1,2,3] A 3D-s modellt az 1. ábra és a 2. ábra szemlélteti.

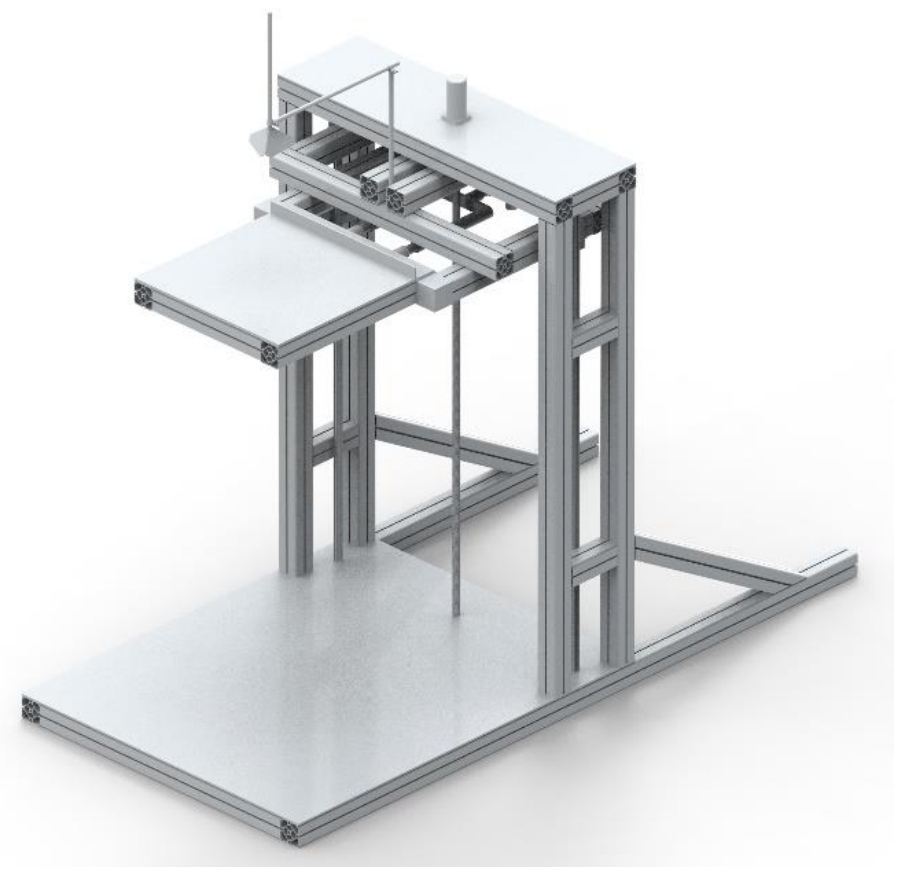

1. ábra A berendezés ST9 környezetben 


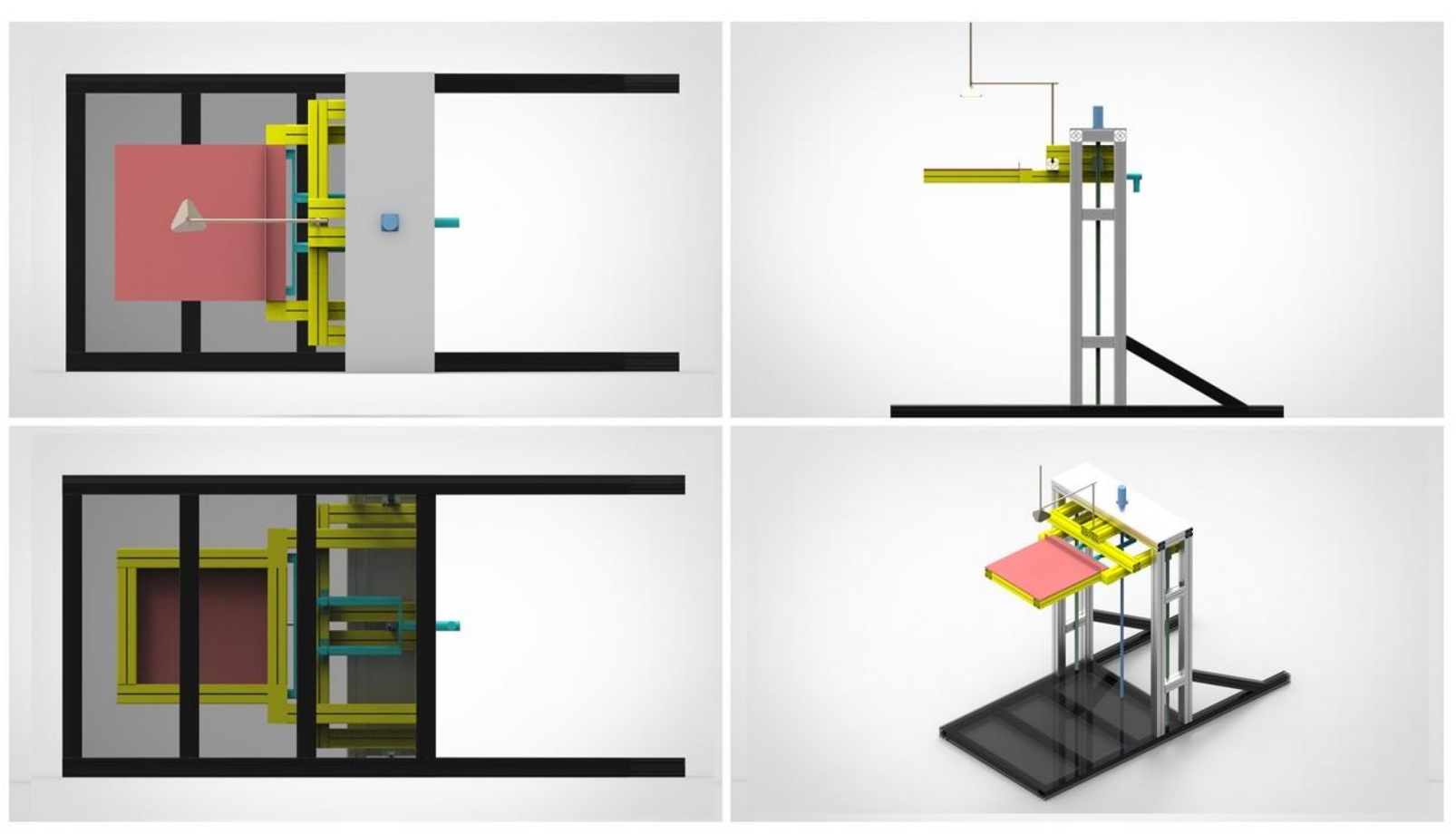

2. ábra Baloldalt fentröl: felül-, jobb- és alulnézet, valamint általános nézet

Az átlátszó fekete színủ elemek jelölik a talpazatot, melyre a váz további része épül és a síklapot, amelyre a csomagot ejtjük. A világosszürke elemek képezik a vázat, melyhez csatlakoznak a további részegységek: két oldalt függőlegesen a zölddel jelölt, megvezetésért felelős lineáris vezetékek és felül kékkel a hajtást biztosító motor. A váz fent említett két részében kap helyet a szintén kékkel jelölt orsó egy-egy csapágyazása. A lineáris vezetékek kocsijaihoz kapcsolódik a sárgával jelölt függőleges mozgást végző tartószerkezet, melyhez az orsón lévő anya is rögzítve van. A sárga tartószerkezethez kapcsolódik még az alábbi három részegység: bronzszínnel jelölve a csomag-pozicionáló rúdszerkezet, pirossal jelölve a billenő tálca, valamint türkiz színben a kioldó mechanizmus.

\section{Véges elemes analízis a meglévő szerkezetre}

A véges elemes analízis az Ansys program 13.0 verziójával készült. Mivel az elvárt ISEL profilok alkalmazása a véges elemes analízishez szükséges behálózás során rengeteg csomópontot (2,3 milliót) eredményezett, bizonyos nem teherviselő elemek eltávolításra kerültek a szerkezetről. Ezáltal nőtt a valószínüsége annak, hogy a program sikeresen lefut, illetve ilyen módon a futási idő is csökken, hiszen ennyi csomópont kiszámítása nagy hardver- és időigényü. Ezzel a módosítással a csomópontok számát 1,44 millióra sikerült lecsökkenteni, az elemek száma 771 ezer. 


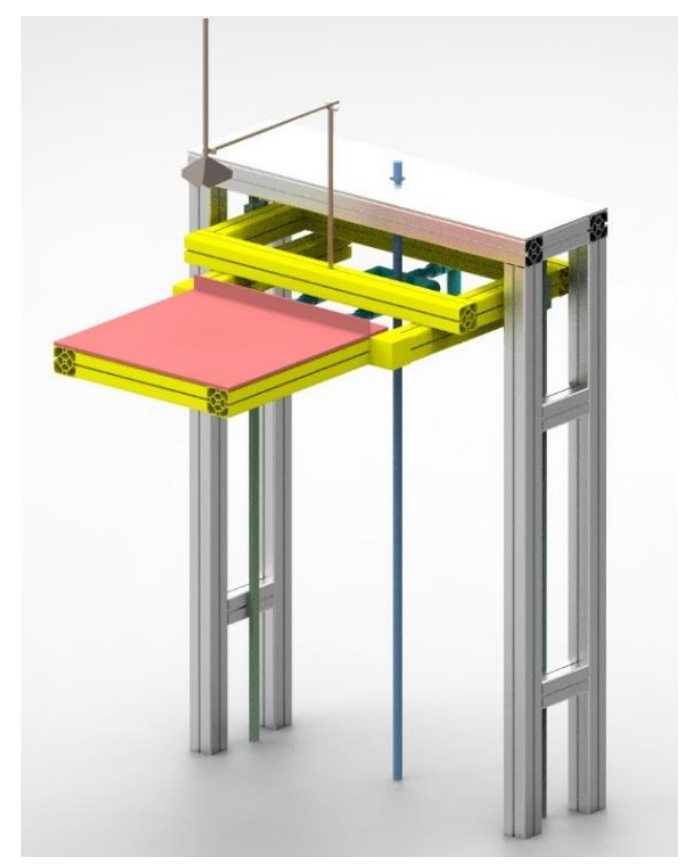

3. ábra Az analizált szerkezeti rész

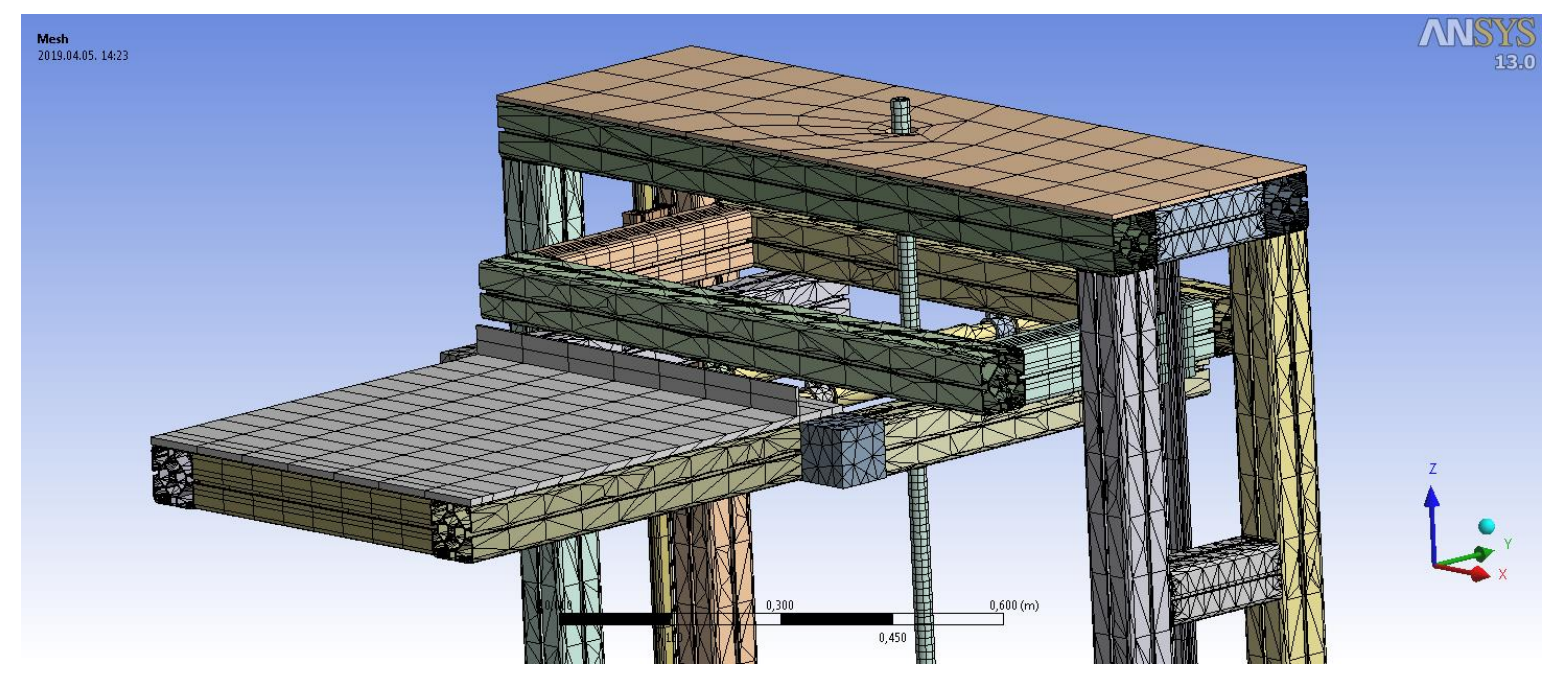

4. ábra A behálózott szerkezet

Az analízis az alábbi módon történt: a négy darab függőleges tartóoszlop-, a két darab függőleges lineáris vezeték- és az orsó alsó végein merev befogás lett definiálva. Peremfeltételként a billenő tálca felső síkján (következő ábrán pirossal jelölve), ahová a csomag kerül, $250 \mathrm{~N}$ erő lett megadva mínusz 'z' irányban, mivel a maximális csomagtömeg $25 \mathrm{~kg}$ (a nehézségi gyorsulás értéke az analízis során $10 \frac{\mathrm{m}}{\mathrm{s}^{2}}$ ). A program futása valamivel több, mint két órát vett igénybe. 


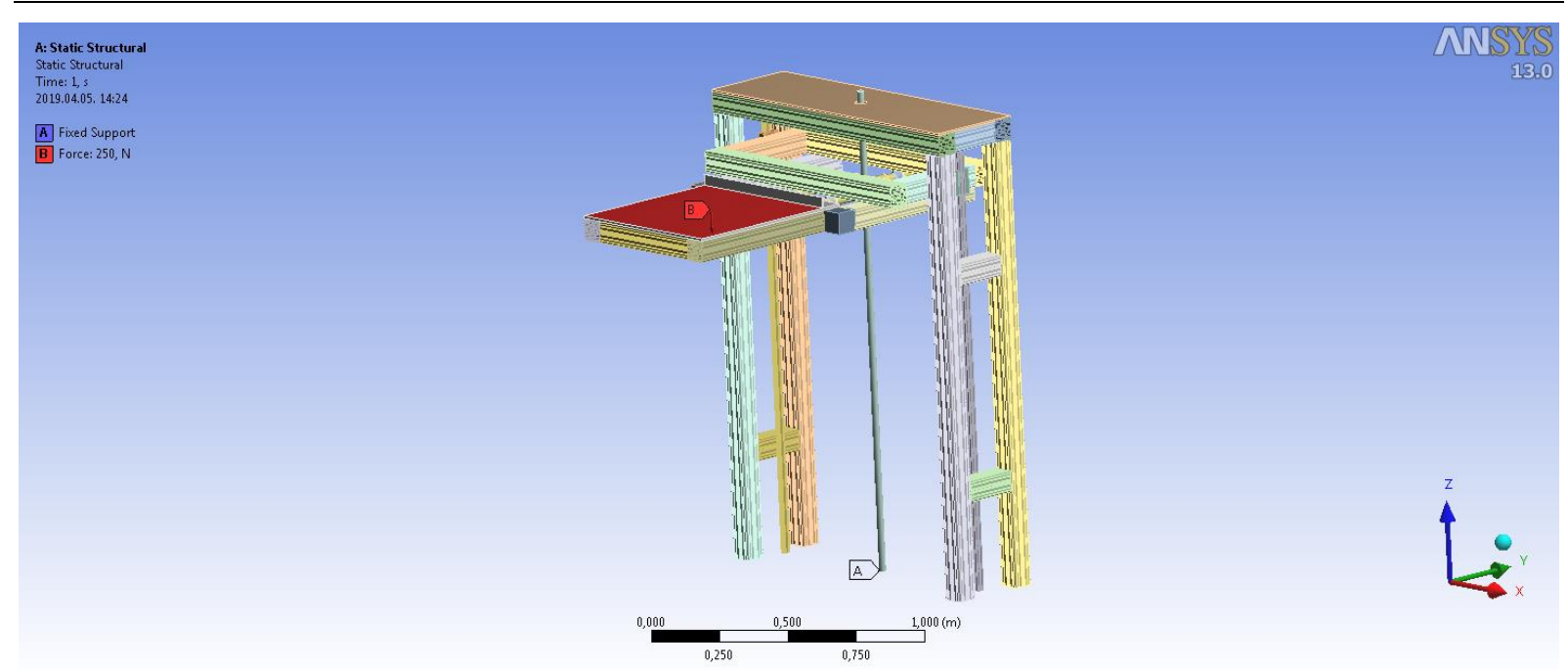

5. ábra Peremfeltételek

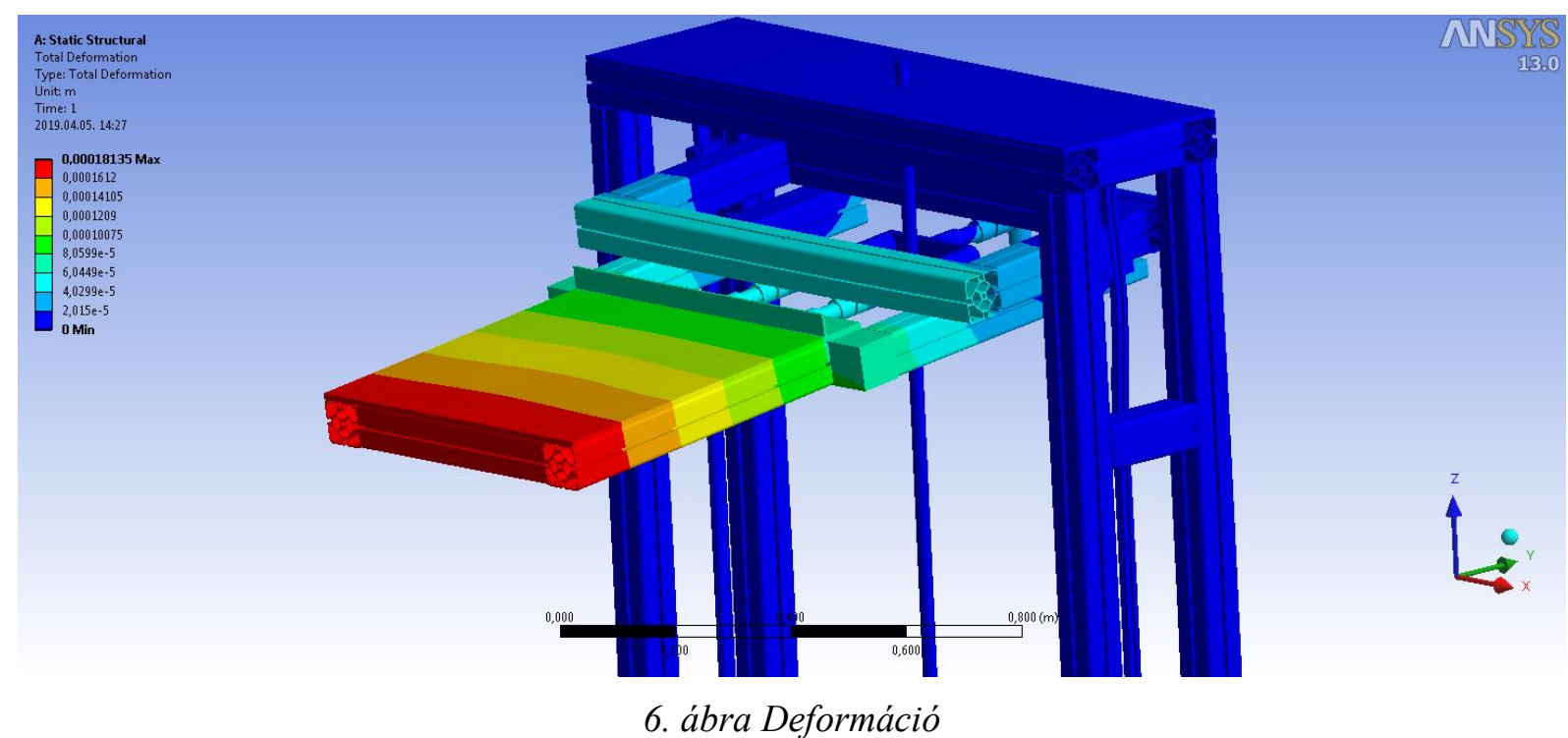

A maximális deformáció nem meglepő módon a tálcának a lineáris vezetékektôl 'y' irányban legtávolabb eső részén történik, értéke csupán $0,18 \mathrm{~mm}$. 


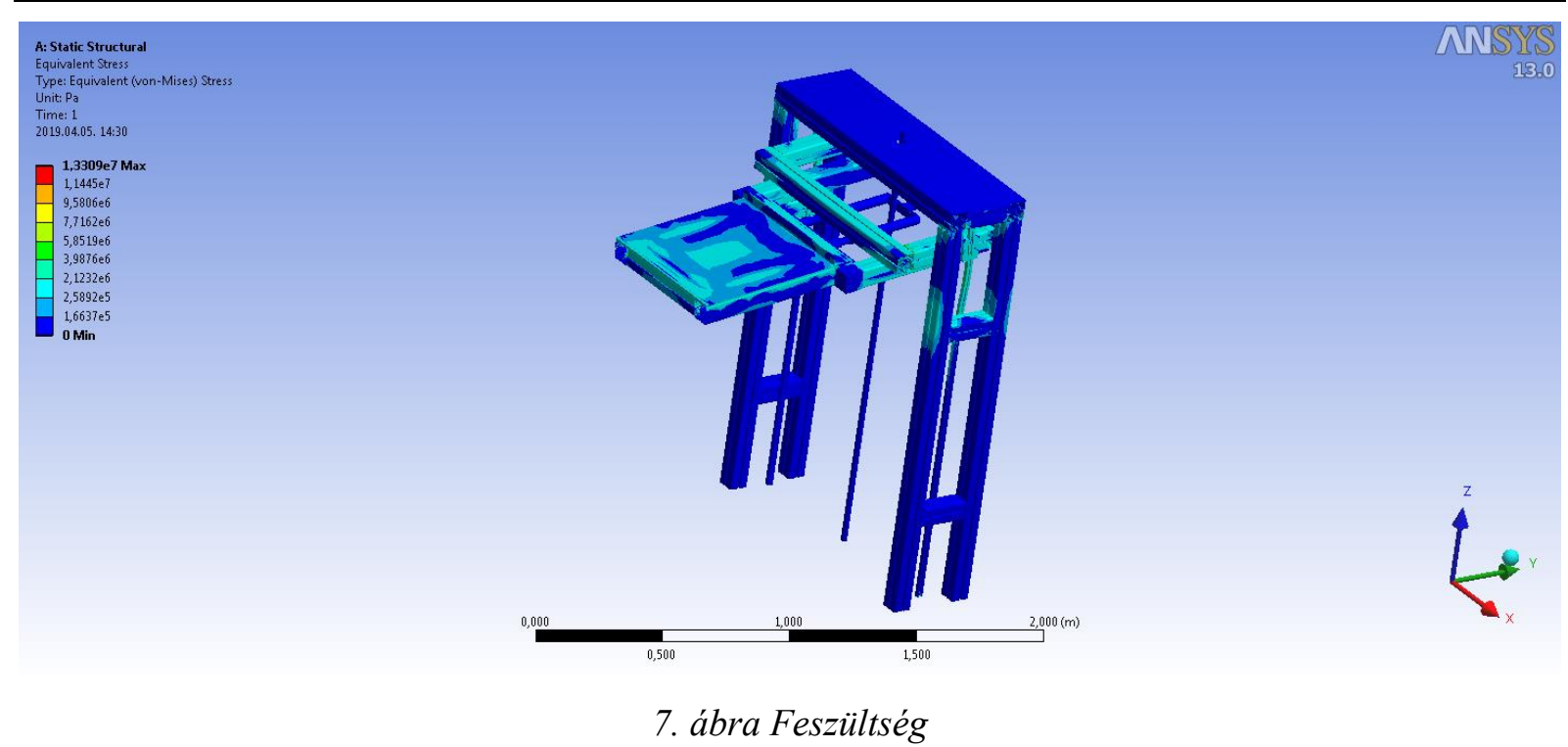

Nagyobb feszültség többnyire a mozgó tálcatartó szerkezetben, a tálcában és a lineáris vezetékben ébred, de nem számottevő mértékben. A maximális feszültség mindössze 13,31 MPa, ami a tálcatartó szerkezet keresztrúdjában ébred.

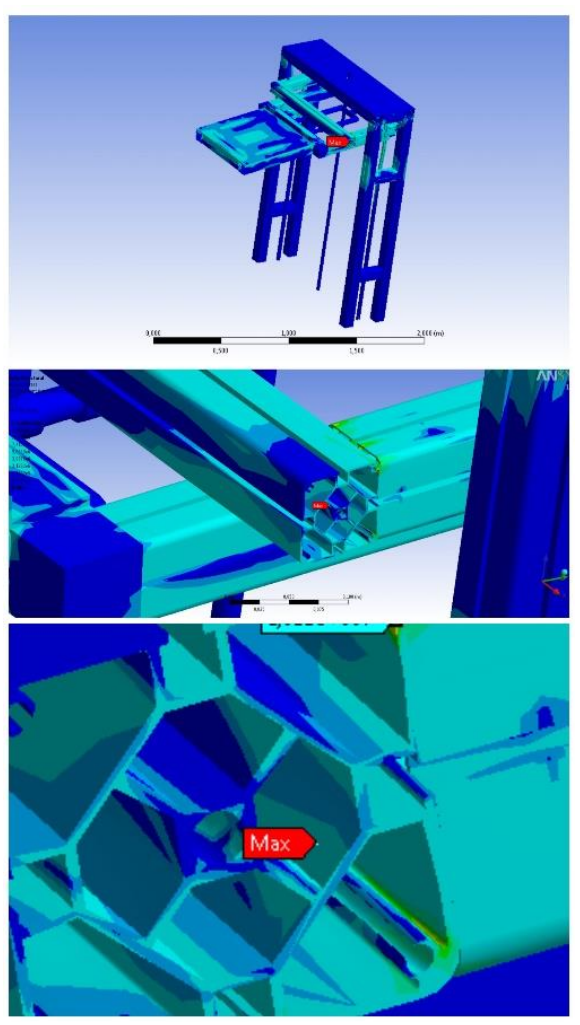

8. ábra Maximális feszültség 
Ezek az értékek arra engednek következtetni, hogy a szerkezet statikai szempontból nagyon jól megfelel, rendelkezik elegendő merevséggel. A tervezés szempontjából viszont arra ad utalást a kis elmozdulás- és viszonylag kicsi maximális feszültség érték, hogy a szerkezet túlméretezett. Ezért a későbbiekben szükséges bizonyos részeket kisebb terhelhetőségü elemekre cserélni, a gazdaságosságot szem előtt tartva. További következtetésként levonható, hogy a szerkezet nem rendelkezik kiugró feszültségcsúccsal, így csak a gazdaságosabb profil választás szükséges, szerkezeti áttervezés nem. [8]

\section{4. Összefoglalás}

A tervezési folyamat első részében az ötletek gyüjtésén és szelektálásán volt a hangsúly, ami a korábbi szabadalmak és a már meglévő, hasonló célra kifejlesztett berendezések elemzésével történt. A szükségesnek vélt funkcionális részegységek alapján megoldásváltozatok megfogalmazására került sor. A megoldásváltozatok értékelemzése alapján a legjobbnak bizonyuló kialakítás képezte a további tervezési feladatok alapját. Solid Edge ST9 szoftver segítségével a berendezésröl egy 3D-s modell készült, ami a végeredményt csekély mértékben befolyásoló módosításokkal ellátva, az Ansys 13.0 véges elemes programmal került ellenőrzésre.

További feladat az orsó és a lineáris vezetékek kiválasztása az ISEL cég katalógusából, majd azoknak a mérnöki számítások alapján történő ellenőrzése. Szükséges még a megfelelő motor kiválasztása. Ezek után a vázszerkezet optimális profilját és az egyéb szükséges gépépítő elemeket is meg kell határozni, majd egy újabb véges elemes vizsgálattal célszerü ellenőrizni a berendezést és ha szükséges, megfelelően módosítani a vázszerkezetet. A távlati tervek közt szerepel a berendezés megépítése is.

\section{Köszönetnyilvánítás}

A cikkben ismertetett kutató munka az EFOP-3.6.1-16-2016-00011 jelü „Fiatalodó és Megújuló Egyetem - Innovatív Tudásváros - a Miskolci Egyetem intelligens szakosodást szolgáló intézményi fejlesztése" projekt részeként - a Széchenyi 2020 keretében - az Európai Unió támogatásával, az Európai Szociális Alap társfinanszírozásával valósul meg.

\section{Irodalom}

[1] Zsáry, Á.: Gépelemek I., Nemzeti Tankönyvkiadó, Budapest, 1989, ISBN: 9631945855

[2] Zsáry, Á.: Gépelemek II., Nemzeti Tankönyvkiadó, Budapest, 1991, ISBN: 96318 6443X

[3] Herczeg, I.: Szerkesztési atlasz, Műszaki Könyvkiadó, Budapest, 1976, ISBN: 9631007901

[4] Péter, J.: A géptervezés alapjai, Miskolci Egyetemi Kiadó, 2017, ISBN:978 9636618377

[5] Rockstroh, O. Csomagolástechnika kézikönyv, Müszaki Könyvkiadó, Budapest, 1979, ISBN: 9631032795

[6] Takács, Á.: Computer Aided Concept Building, Solid State Phenomena 261, 2017, pp.402-407, https://doi.org/10.4028/www.scientific.net/SSP.261.402

[7] Takács, Á., Kamondi, L.: On Design Theories: Fundamentals of a Neuvel Approach, Advanced Engineering 5 Vol.1, 2011, pp. 109-118.

[8] Szabó, F. J.: Optimization possibilities and methods in product development and qualification, Design of Machines and Structures, 1 Vol 2, 2012. ISSN: 1785-6892 